\title{
The Green Deal Umbrella for Environmental and Climate Technologies
}

\section{Preface}

This special issue is devoted to CONECT 2020, a scientific conference organised by the Institute of Energy Systems and Environment, Riga Technical University. The conference has brought together scientists from 5 continents and 20 countries, even though COVID 19 dictated its conditions - this time the event took place online. The international conference CONECT 2020 united participants under the Green Deal umbrella, paying close attention to technological problems of environment and climate, raising questions and offering solutions.

Signed by European Union member countries, the Green Deal has taken scientists' interest beyond technological solutions research. Bigger than usual attention is paid to the policy analysis of environment and climate issues that are viewed from the perspective of resource users and their level of awareness, for instance, finding out whether hugs, carrots and sticks are essential for an effective energy policy in Latvia or not, or analysing education for advancing the implementation of the bioeconomy goals - an analysis of master study programmes in bioeconomy, as well as identifying blind spots of energy transition policy in the context of Latvia.

Improvement of energy efficiency at the level of energy producers and users is what this year's papers pay special attention to. Technological processes of manufacturing organisations are being analysed for the production of environmentally friendly tableware, energy efficiency improvement in thawing, multi-criteria evaluation of efficiency in fish processing, current thermal comfort assessment in an administrative area of an industrial building in Spain.

One of the topical issues - the use of renewable energy resources in buildings - has been explored in various ways. For instance, conducting research on solar electricity over three continents, the use of biomass in onefamily buildings, for which treatment of particulate matter pollution is relevant in the context of people's attitude and readiness to act, methods for determining the performance and efficiency parameters of the flue-gas condenser sedimentation tank.

The reduction in energy consumption in buildings is reviewed from various perspectives: inverse modeling of climate adaptive building shells, the relationship between energy demand and indoor thermal behaviour concerning passive energy-refurbishment interventions, implementation of certified energy management system in municipality, as well as evaluation of the effect of different base temperatures to calculate degree days.

Regional energy policy is analysed using various methods, for example, methodology of indicative analysis to determine the territories for implementation of the energy saving strategy by example of Eastern Siberia region, life cycle assessment of low temperature district heating system in Gulbene region, as well as system dynamics modelling of railway electrification and energy sustainability index in statistical regions of Latvia. 
Circular economy aspects of climate technologies are evaluated through the prism of diverse bioeconomy issues, for example, bioeconomy investments: market considerations and transdisciplinary bioeconomy research by use of difference between bibliometric and grey data.

Production of bioenergy opportunities in bioeconomy become more and more topical, for example, novel Stacked Modular Open Raceway Ponds (SMORPs) for microalgae biomass cultivation in biogas plants: preliminary design and modelling, perennial grasses as a substrate for bioethanol production, effect of combining different substrates and inoculum sources on bioelectricity generation and COD removal in a two-chambered microbial fuel cell: a preliminary investigation; techno-economic analysis of biofuel production plants producing biofuels using Fisher Tropsch synthesis; biorefinery potential and extraction technologies for seaweed-based systems: a review for Easter Baltic seaweeds and the potential of chlorella species as a feedstock for bioenergy production.

Another aspect of bioeconomy is revealed using particular elements in bioresources chain, for example, effect of N:P ratio on microalgae/nitrifying bacteria community in agrodigestate treatment, and ranking of by-products for single cell oil production in the context of Latvia.

Wishing all our readers exciting hours while becoming acquainted with fresh ideas and innovative scientific methodological approach that will inspire scientists to make contribution to our next volumes.

\section{Professor Dagnija Blumberga}

Director of Institute of Energy Systems and Environment Riga Technical University, Latvia 